\title{
Focal epilepsy with ictal abdominal pain: a case report
}

\author{
Caterina Cerminara, Nadia El Malhany*, Denis Roberto and Paolo Curatolo
}

\begin{abstract}
Focal epilepsy with ictal abdominal pain is an unusual partial epilepsy characterized by paroxysmal episodes of abdominal or visceral pain, disturbance of awareness and electroencephalographic abnormalities. We describe a new case of ictal abdominal pain in which gastrointestinal complaints were the only manifestation of seizures and review the previously described pediatric patients. In our patient clinical findings, ictal EEG abnormalities, and a good response to antiepileptic drugs allowed us to make a diagnosis of focal epilepsy with ictal abdominal pain. This is a rare epileptic phenomenon that should be suspected in patients with unexplained paroxysmal abdominal pain and migraine-like symptoms. We suggest that, after the exclusion of more common etiologies, focal epilepsy with ictal abdominal pain should be considered in patients with paroxysmal abdominal pain and ictal EEG abnormalities.
\end{abstract}

\section{Introduction}

Recurrent episodes of abdominal pain are common in children and adults. Several pathological conditions can lead to paroxysmal gastrointestinal symptoms, such as porphiria, cyclical vomiting, intestinal malrotation, peritoneal bands, and abdominal migraine [1]. Psychological and emotional factors may also play an important role in some patients with gastrointestinal disorders. However, in a number of patients the episodic nature of abdominal pain can be suggestive for a diagnosis of epilepsy [1]. Epileptiform EEG abnormalities, loss or alteration of consciousness, and a good response to antiepileptic drugs are other features that can lead to a diagnosis of focal epilepsy with ictal abdominal pain $[2,3]$. We describe one child affected by epilepsy which had recurrent and severe abdominal pain as the only manifestation of epileptic seizures.

\section{Case report}

An 8-year-old boy was born at 39 weeks of gestation by selective cesarean section. The pregnancy was complicated by a sudden reduction in fetal heart rate. All developmental milestones were regularly achieved. There was no family history of epilepsy. The boy experienced recurrent episodes of abdominal pain since about 6 months of

\footnotetext{
* Correspondence: elm.nadia@gmail.com

Department of Neuroscience, Paediatric Neurology Unit, "Tor Vergata" University of Rome, Viale Oxford, 81, 00133 Rome, Italy
}

age. He described the pain as "a sword that pierces my belly", localized mainly in the epigastric region and its duration varied from a few minutes (more frequently) to 1 hour, with a frequency of 5-8 episodes per day. The intensive abdominal pain was almost always associated with pallor and nausea, but not accompanied by scream or cry. The attacks were sudden in onset and had spontaneous resolution. There was no impairment of consciousness, also in longer episodes, and he never had convulsions; the paroxysms were followed by increased sleep. He underwent a negative abdominal investigation including complete blood count, stool examinations for ova and parasites, abdominal ultrasound and upper gastrointestinal endoscopy. Physical and neurological examinations were normal.

Interictal EEG during wakefulness and sleep displayed bilateral spikes and diphasic sharp-waves localized over the temporal leads with a marked increase in frequency during drowsiness. A 24-hours EEG recording showed several bilateral synchronous and asynchronous temporal spikes during wakefulness and nocturnal sleep. At 9:30 in the morning a seizure characterized by severe abdominal pain in the epigastric region with nausea and pallor was recorded. The ictal EEG showed rhythmic spikes on the centro-temporal regions (Figure 1). Magnetic resonance imaging of the brain was normal. The patient started treatment with Carbamazepine (CBZ) $(20 \mathrm{mg} / \mathrm{kg} /$ day $)$ with a 


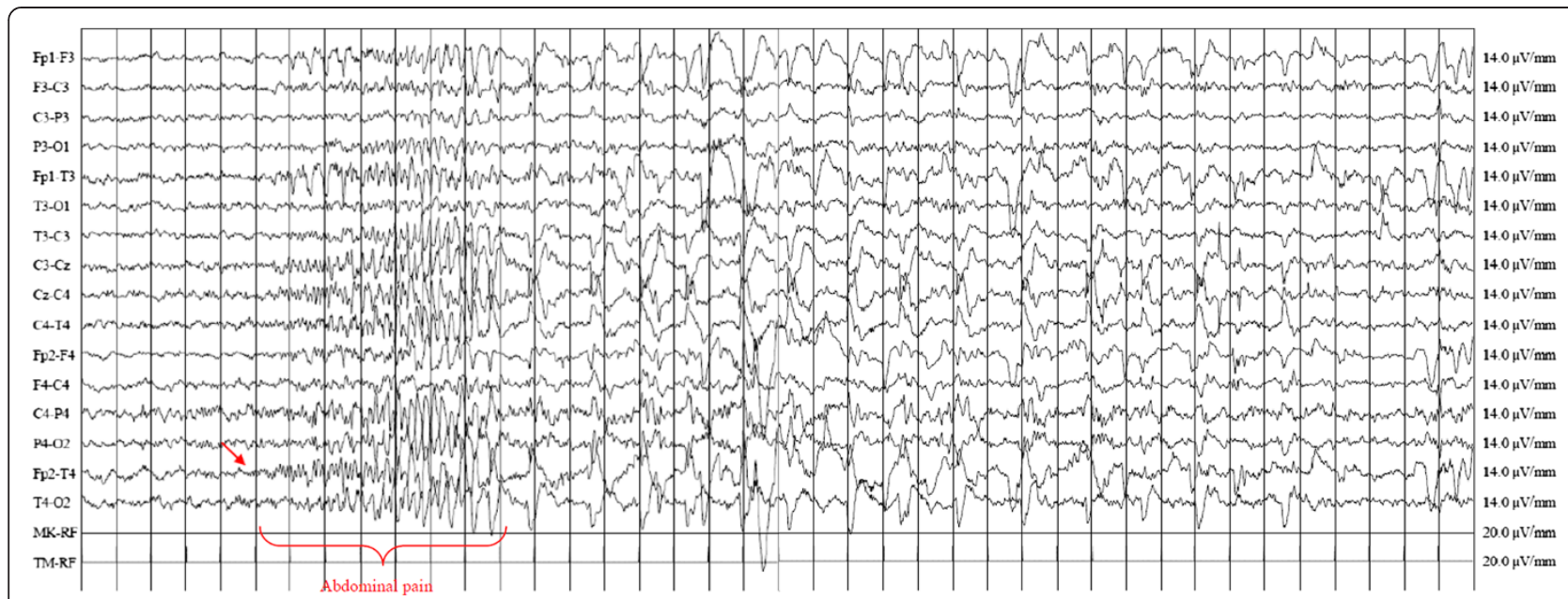

Figure 1 Ictal awake EEG showing runs of rhythmic spikes and sharp waves, over the right fronto-temporal electrodes. The onset and offset of abdominal pain are closely related to the beginning and end of the discharge.

progressive decrease in seizure frequency. At the last follow-up, when he was 9-years old, he was seizure free.

\section{Discussion}

Epigastric sensations are frequent symptoms in patients with partial epilepsy and may include abdominal pain, nausea, vomiting and hunger, and have been reported to be the most common aura in temporal lobe epilepsy [3-5]. Painful epileptic auras were reported in $4.1 \%$ of 25 patients with focal epilepsy by Nair et al. [6]. Abdominal pain was present in $5 \%$ of all abdominal auras in temporal lobe epilepsy and $50 \%$ in frontal lobe epilepsy [6]. However, gastrointestinal complaints, in particular abdominal pain, may be the only manifestation of epileptic activity $[1,3,4,7]$. Unexplained paroxysmal gastrointestinal complaints, impairment of consciousness, and focal abnormal EEG are the main criteria to establish a diagnosis of focal epilepsy with ictal abdominal pain, but not all the criteria need to be present in each case $[2,3,6]$. In addition, a variety of migraine-like disturbances such as nausea, headache, dizziness, and visual hallucinations may be associated with pain during the attacks [4]. When the migraine-like symptoms are present it is often difficult to differentiate focal epilepsy with ictal abdominal pain from migraine or other neurological disorders, such as Panayiotopoulos syndrome. The abrupt onset, the spontaneous resolution, and the relatively short duration of episodes may be helpful for a correct and early diagnosis of focal epilepsy with ictal abdominal pain. Another helpful distinguishing feature of epilepsy with severe abdominal pain could be the localization of ictal pain, that is most commonly periumbilical or upper abdominal and rarely spreads to involve other body parts, such as in our patient [1-4].

EEG abnormalities have been reported in most patients with focal epilepsy and ictal abdominal pain [1,4]. Few reports described ictal EEGs: during the seizure the EEG often shows a runs of high voltage slow waves and generalized spike and wave discharges $[2-4,8]$. In our patient, 24hours EEG was suggestive of a focal onset, as in two reports that showed clear focal EEG changes over the left hemisphere during an episode of abdominal pain $[9,10]$. Table 1 shows the clinical characteristics of our patient and the previous pediatric cases described in literature (Table 1) [1-5,7-13].

The pathophysiology of focal epilepsy with ictal abdominal pain remains unknown. Abdominal sensations reproduced by stimulating the insula and sylvian fissure, suggest that these areas may have an important role in explaining the origin of focal epilepsy with ictal abdominal pain [3]. Phan et al. [14], reported an unusual case of ictal abdominal pain occurring in the setting of parietal lobe haemorrhage and suggested a possible role of the somatosensory area in pain perception. Supplementary motor area was considered as another possible location for abdominal pain. Occasionally focal epilepsy with ictal abdominal pain has been related to brain tumors and brain disorders $[2,8]$. Previous reports on ictal abdominal pain have shown right parieto-occipital encephalomalacia, biparietal atrophy and bilateral perisylvian polymicrogyria [9].

In conclusion, our patient showed recurrent attacks of severe abdominal pain as the only manifestation of epileptic seizure. Focal epilepsy with ictal abdominal pain is a rare epileptic phenomenon that should be suspected in patients with unexplained paroxysmal abdominal pain and migraine-like symptoms. The correct diagnosis at the onset may be difficult to establish; in these cases prolonged EEG recordings with 24-hours monitoring must be considered to facilitate the clinical diagnosis. 
Table 1 Clinical characteristics of reported cases of abdominal epilepsy in pediatric population and in our patient

\begin{tabular}{|c|c|c|c|c|c|c|c|c|}
\hline $\begin{array}{l}\text { Patient } \\
\text { number }\end{array}$ & Age & Sex & $\begin{array}{l}\text { Gastrointestinal } \\
\text { symptoms }\end{array}$ & $\begin{array}{l}\text { Other non- } \\
\text { gastrointestinal } \\
\text { symptoms }\end{array}$ & $\begin{array}{l}\text { Episode } \\
\text { duration }\end{array}$ & EEG & Treatment & Outcome \\
\hline $\begin{array}{l}\text { Zdravescka } \\
\text { N. et al. }{ }^{1}\end{array}$ & 14 & $\mathrm{~F}$ & $\begin{array}{l}\text { Colicky epigastric } \\
\text { pain, nausea, } \\
\text { vomiting and } \\
\text { diarrhea }\end{array}$ & Pallor, dizziness & $\begin{array}{l}10-30 \\
\text { minutes }\end{array}$ & $\begin{array}{l}\text { Spikes, sharp waves over the right central and temporal } \\
\text { regions with secondary generalization }\end{array}$ & Carbamazepine & Seizure free \\
\hline $\begin{array}{l}\text { Franzon RC } \\
\text { et al. }^{2}\end{array}$ & 6 & $\mathrm{~F}$ & Abdominal pain & $\begin{array}{l}\text { Disturbed awareness, } \\
\text { occasional generalized } \\
\text { tonic-clonic seizures }\end{array}$ & $\begin{array}{l}\text { Seconds } \\
\text { to minutes }\end{array}$ & Spikes and slow waves over left temporal area & $\begin{array}{l}\text { Anticonvulsants, surgical } \\
\text { resection of oligoastrocytoma }\end{array}$ & Seizure free \\
\hline $\begin{array}{l}\text { Garcia- } \\
\text { Herrero D. } \\
\text { et al. }\end{array}$ & 14 & $\mathrm{~F}$ & $\begin{array}{l}\text { Colicky periumbilical } \\
\text { pain }\end{array}$ & $\begin{array}{l}\text { Headache, pallor, dizziness, } \\
\text { multicolored photopsia }\end{array}$ & $\begin{array}{l}\text { Second to } \\
\text { minutes }\end{array}$ & Interictal-bursts of sharp and slow waves & Valproic acid & $\begin{array}{l}\text { Near } \\
\text { complete } \\
\text { resolution }\end{array}$ \\
\hline $\begin{array}{l}\text { Dutta SR } \\
\text { et al. }{ }^{4}\end{array}$ & 15 & M & $\begin{array}{l}\text { Epigastric abdominal } \\
\text { pain and vomiting }\end{array}$ & Lethargy & $\begin{array}{l}30 \text { minute } \\
\text { to hours }\end{array}$ & Right temporal focal seizure discharge with generalization & Oxcarbazepine & Seizure free \\
\hline \multicolumn{9}{|l|}{ Case 1} \\
\hline $\begin{array}{l}\text { Dutta SR } \\
\text { et al. }{ }^{4}\end{array}$ & 13 & $\mathrm{~F}$ & $\begin{array}{l}\text { Colicky periumbilical } \\
\text { pain }\end{array}$ & NR & $\begin{array}{l}10-30 \\
\text { minutes }\end{array}$ & Generalized spikes and wave discharges & Oxcarbazepine & Seizure free \\
\hline \multicolumn{9}{|l|}{ Case 2} \\
\hline $\begin{array}{l}\text { Young GB } \\
\text { et al. } .^{5}\end{array}$ & 15 & $\mathrm{~F}$ & Abdominal pain & Generalized tonic seizures & NR & Multiple independent spikes & NR & NR \\
\hline $\begin{array}{l}\text { Hasan } \mathrm{N} \text {. } \\
\text { et al. }\end{array}$ & 8 & M & $\begin{array}{l}\text { Colicky periumbilical } \\
\text { pain, vomiting }\end{array}$ & $\begin{array}{l}\text { Pallor, an episode with } \\
\text { jerky movements in the } \\
\text { lower limbs }\end{array}$ & $\begin{array}{l}10- \\
30 \text { minutes }\end{array}$ & $\begin{array}{l}\text { Generalized paroxysmal epileptiform activity, maximum on } \\
\text { photic stimulation }\end{array}$ & Valproic acid & Seizure free \\
\hline $\begin{array}{l}\text { Siegel AM } \\
\text { et al. } .^{8}\end{array}$ & 1 & $\mathrm{~F}$ & $\begin{array}{l}\text { Crampy periumbilical } \\
\text { pain }\end{array}$ & $\begin{array}{l}\text { Occasional generalized } \\
\text { seizures }\end{array}$ & $\begin{array}{l}\text { Few } \\
\text { seconds }\end{array}$ & Right parietal focus & NR & NR \\
\hline $\begin{array}{l}\text { Mitchell } \\
\text { WG et al. }{ }^{9}\end{array}$ & 6 & M & Vomiting & Bad smell, fatigue & $\begin{array}{l}20-40 \\
\text { seconds }\end{array}$ & $\begin{array}{l}\text { Ictal and intercritic high voltage arrhythmic delta waves, } \\
\text { sometimes sharply contoured }\end{array}$ & $\begin{array}{l}\text { Multiple antiseizure } \\
\text { medication, than surgary and } \\
\text { radiation (for astrocytoma) }\end{array}$ & $\begin{array}{l}\text { Decreased } \\
\text { frequency of } \\
\text { episodes }\end{array}$ \\
\hline $\begin{array}{l}\text { Douglas EF } \\
\text { et al. }{ }^{10} \\
\text { Case } 1\end{array}$ & 11 & $\mathrm{~F}$ & $\begin{array}{l}\text { Paroxysmal, peri- } \\
\text { umbilical abdominal } \\
\text { pain }\end{array}$ & $\begin{array}{l}\text { Lassitude, post-ictal sleep, } \\
\text { fever, headache, } \\
\text { confusion. }\end{array}$ & "Brief" & Irregular $3 \mathrm{~Hz}$ spike-waves activity & Phenobarbital & Seizure free \\
\hline $\begin{array}{l}\text { Douglas EF } \\
\text { et al. }{ }^{10}\end{array}$ & 5 & $\mathrm{~F}$ & $\begin{array}{l}\text { Crampy, paroxysmal } \\
\text { abdominal pain }\end{array}$ & Lethargy, post-ictal sleep & $\begin{array}{l}\text { Few } \\
\text { minutes }\end{array}$ & $\begin{array}{l}\text { Episode } 6-7 \text { activity in } L \text { temporal area, burst of } \\
\text { generalized irregularly intermixed spikes and slow waves }\end{array}$ & Phenobarbital & $\begin{array}{l}\text { Lost to } \\
\text { follow-up }\end{array}$ \\
\hline \multicolumn{9}{|l|}{ Case 2} \\
\hline $\begin{array}{l}\text { Douglas EF } \\
\text { et al. }{ }^{10}\end{array}$ & 6 & M & Paroxysmal pain & Lethargy, confusion, fever & $\begin{array}{l}\text { Few } \\
\text { minutes }\end{array}$ & Paroxysmal spike-wave activity, frontal or generalized & Anticonvulsivants & Seizure free \\
\hline \multicolumn{9}{|l|}{ Case 3} \\
\hline $\begin{array}{l}\text { Yingkun } \\
F^{11}\end{array}$ & 3 & M & $\begin{array}{l}\text { Abdominal pain, } \\
\text { vomiting }\end{array}$ & $\begin{array}{l}\text { Confusion, cyanosis, } \\
\text { urinary incontinence, } \\
\text { blindness }\end{array}$ & $\begin{array}{l}\text { Few } \\
\text { minutes }\end{array}$ & $\begin{array}{l}\text { Scattered high voltage slow activity and high voltage } \\
\text { sharp waves }\end{array}$ & Phenytoin, phenobarbital & Seizure free \\
\hline
\end{tabular}


Table 1 Clinical characteristics of reported cases of abdominal epilepsy in pediatric population and in our patient (Continued)

\begin{tabular}{|c|c|c|c|c|c|c|c|c|}
\hline \multicolumn{9}{|l|}{ Case 1} \\
\hline $\begin{array}{l}\text { Yingkun } \\
F^{11}\end{array}$ & 16 & M & $\begin{array}{l}\text { Upper abdominal } \\
\text { pain, nausea }\end{array}$ & $\begin{array}{l}\text { Disturbance of } \\
\text { consciousness }\end{array}$ & $\begin{array}{l}3-5 \\
\text { minutes }\end{array}$ & $\begin{array}{l}\text { High voltage slow waves; high voltage sharp waves with } \\
\text { hyperventilation }\end{array}$ & Phenobarbital & Seizure free \\
\hline \multicolumn{9}{|l|}{ Case 2} \\
\hline $\begin{array}{l}\text { Yingkun F } \\
\text { et al. }{ }^{11}\end{array}$ & 11 & $\mathrm{~F}$ & $\begin{array}{l}\text { Periumbilical } \\
\text { abdominal pain }\end{array}$ & $\begin{array}{l}\text { Disturbance/loss of } \\
\text { consciousness }\end{array}$ & $\begin{array}{l}\text { Minutes to } \\
\text { hour }\end{array}$ & Bilateral high voltage spikes, complexed slow waves & Phenytoin, phenobarbital & Seizure free \\
\hline \multicolumn{9}{|l|}{ Case 3} \\
\hline $\begin{array}{l}\text { Singhi PD } \\
\text { et al. }{ }^{12}\end{array}$ & 10 & M & Periumbilical pain & $\begin{array}{l}\text { Pallor, sweates, lethargy, } \\
\text { post-ictal sleep }\end{array}$ & $\begin{array}{l}\text { Few } \\
\text { minutes }\end{array}$ & $\begin{array}{l}\text { Sharp spikes, spikes and wave activity arising over the } \\
\text { central region and becoming generalized }\end{array}$ & Phenytoin & $\begin{array}{l}\text { Complete } \\
\text { resolution }\end{array}$ \\
\hline $\begin{array}{l}\text { Agrawal P. } \\
\text { et al. }{ }^{13}\end{array}$ & 6 & M & $\begin{array}{l}\text { Colicky periumbilical } \\
\text { pain }\end{array}$ & Lassitude, post-ictal sleep & $\begin{array}{l}\text { Half an } \\
\text { hour }\end{array}$ & Generalized slowing, right posterior spikes & Carbamazepine & Seizure free \\
\hline Our patient & 8 & M & $\begin{array}{l}\text { Colicky epigastric } \\
\text { pain, nausea }\end{array}$ & Pallor & $\begin{array}{l}\text { Few } \\
\text { minutes to } \\
1 \text { hour }\end{array}$ & $\begin{array}{l}\text { Bilateral synchronous and asynchronous spikes and } \\
\text { diphasic sharp-waves in temporal and central area, } \\
\text { increased during drowsiness and sleep }\end{array}$ & Carbamazepine & Seizure free \\
\hline
\end{tabular}




\section{Consent}

Written informed consent was obtained from the patient's parents for the publication of this report.

\section{Competing interests}

The authors declare that they have no financial and non-financial competing interests.

\section{Authors' contributions}

CC (Medical Doctor) drew the first draft with the assistance and contribution of NEM (Medical Doctor); DR (Medical Doctor) reviewed relevant articles on the literature under the supervision of PC (Director of the Department of Pediatric Neuroscience Unit); PC revised the final draft. All authors

contributed to the intellectual contents and approved the final version.

Received: 7 October 2013 Accepted: 4 December 2013

Published: 9 December 2013

\section{References}

1. Zdraveska N, Kostovski A: Epilepsy presenting only with severe abdominal pain. J Pediatr Neurosci 2010, 5(2):169-70. 10.4103/1817-1745.76123.

2. Franzon RC, Lopes CF, Schmutzler KM, Morais Ml, Guerreiro MM: Recurrent abdominal pain: when should an epileptic seizure be suspected? Arq Neuropsiquiatr 2002, 60(3-A):628-30.

3. García-Herrero D, Fernández-Torre JL, Barrasa J, Calleja J, Pascual J: Abdominal epilepsy in an adolescent with bilateral perisylvian polymicrogyria. Epilepsia 1998, 39(12):1370-4.

4. Dutta SR, Hazarika I, Chakravarty BP: Abdominal epilepsy, an uncommon cause of recurrent abdominal pain: a brief report. Gut 2007, 56(3):439-41.

5. Young GB, Blume WT: Painful epileptic seizures. Brain 1983, 106(Pt 3):537-54.

6. Nair DR, Najm I, Bulacio J, Lüders H: Painful auras in focal epilepsy. Neurology 2001, 57(4):700-2.

7. Hasan N, Razzaq A: Abdominal epilepsy. J Coll Physicians Surg Pak 2004, 14(6):366-7.

8. Siegel AM, Williamson PD, Roberts DW, et al: Localized pain associated with seizures originating in the parietal lobe. Epilepsia 1999, 40(7):845-855

9. Mitchell WG, Greenwood RS, Messenheimer JA: Abdominal epilepsy. Cyclic vomiting as the major symptom of simple partial seizures. Arch Neurol 1983, 40(4):251-2.

10. Douglas EF, White PT: Abdominal epilepsy-a reappraisal. J Pediatr 1971, 78(1):59-67.

11. Yingkun F: Abdominal epilepsy. Chin Med J 1980, 93(3):135-148.

12. Singhi PD, Kaur S: Abdominal epilepsy misdiagnosed as psychogenic pain. Postgrad Med J 1988, 64(750):281-282

13. Agrawal P, Dhar NK, Bhatia MS, Malik SC: Abdominal epilepsy. Indian J Pediatr 1989, 56(4):539-541.

14. Phan TG, Cascino GD, Fulgham J: Ictal abdominal pain heralding parietal lobe haemorrhage. Seizure 2001, 10(1):56-9.

\section{Submit your next manuscript to BioMed Central and take full advantage of:}

- Convenient online submission

- Thorough peer review

- No space constraints or color figure charges

- Immediate publication on acceptance

- Inclusion in PubMed, CAS, Scopus and Google Scholar

- Research which is freely available for redistribution 